\title{
Hydroids (Cnidaria, Hydrozoa) from marine environments in Taiwan
}

\author{
Li-Chun Tseng $^{1 \dagger}$, Cheng-Han Wu', Wen-Hung Twan², Zhi-Can Tang ${ }^{3+}$ and Jiang-Shiou Hwang ${ }^{1 *}$
}

\begin{abstract}
Background: Hydroids were identified from extensive surveys of benthos, and especially from worm tubes, in the Danshuei River estuary (DRE), in the northeast Taiwan Strait (NETS), and on a reef in Nanwan Bay (NWB), Taiwan.

Results: A total of 33 species (12 of them identified to generic and 1 to family rank only), referable to 22 genera, 12 families, and 2 orders, were distinguished. The majority of them were referable to order Leptothecata (84.8\%) with the remainder being assigned to order Anthoathecata (15.2\%). The only species found at NETS was Monoserius pennarius (Linnaeus, 1758). Plumularia habereri (Stechow, 1909) was recorded at both DRE and NWB. The known range of Dynamena nanshaensis (Tang, 1991), recorded for the second time, is extended further north. Six species (Aglaophenia latecarinata, Plumularia floridana, Diphasia palmata, Dynamena brevis, Dynamena obliqua, Synthecium elegans) are recorded for the first time in waters adjacent to the Chinese mainland.
\end{abstract}

Conclusions: Species composition and abundances varied considerably from one environment to another and especially between DRE and NWB. This study provides the first taxonomic account of the hydroid fauna inhabiting the eastern Taiwan Strait region.

Keywords: Cnidaria; Hydroids; Reef; Worm tube; Taiwan; East China Sea; South China Sea

\section{Background}

Hydroids are largely sessile epibenthic cnidarians that inhabit all marine habitats from shallow to abyssal waters (Vervoort 1966). Since hydroids feed on plankton, they likely play an important role in marine ecosystems (Gili and Hughes 1995). Hydroids are often found growing on other marine organisms, including sponges (Calder 1991b), other hydroids (Tang 1991b), deep-sea corals (Henry 2001), molluscs (Kubota et al. 1999), arthropods (Genzano 2002), and macroalgae (Fraschetti et al. 2006; Cunha and Jacobucci 2010; Oliveira and Marques 2007). Except for the well-known association between proboscidactylid polyps and sabellid polychaetes (Schuchert 2009), relatively, little attention has been given to worm tubes as substrates for hydroids.

Several studies on hydroids from temperate and tropical waters of the northwest Pacific have been carried out over the past few decades. These include the fauna

\footnotetext{
* Correspondence: jshwang@mail.ntou.edu.tw

${ }^{\dagger}$ Equal contributors

'Institute of Marine Biology, College of Life Sciences, National Taiwan Ocean University, 2 Pei-Ning Road, Keelung 20224, Taiwan

Full list of author information is available at the end of the article
}

of Japan to the north (e.g., Hirohito 1988, 1995), the Yellow Sea (Tang and Huang 1986), the East China Sea (Tang and Xu 1978; Liu and Li 2002), the Taiwan Strait (Kubota et al. 1999; Xu and Huang 2004), the Philippine Islands (Hargitt 1924), and the South China Sea (Tang 1991a, b, 1998; Yeh 1995; Zhao 1998). Liu (2008) and Huang and Lin (2012) provided checklists and illustrations of Hydrozoa in waters adjacent to mainland China. A number of earlier reports explored the rich hydroid fauna of the western Pacific Ocean (for some references, see Vervoort 1995). Literature is scanty on hydroids from waters of northeast Taiwan (Jäderholm 1903), from the coast of southern Taiwan (Yeh 1995), around Taiwan (Hwang and Shao 1998), in the middle part of the western coast of Taiwan (Kubota et al. 1999), in the Taiwan Strait (Xu and Huang 2004), and from coral reef areas of the country (Fontana et al. 2012). So far, distribution and species composition of hydroids have not been explored in the eastern Taiwan Strait. The present study was undertaken to establish a baseline of information on the group in waters of Taiwan.

\section{空




\section{Methods}

Field sampling and samples treatment

Investigations on hydroids were undertaken in three environmentally distinct regions: (1) the Danshuei River estuary (DRE, $25^{\circ} 10^{\prime} \mathrm{N}, 121^{\circ} 24^{\prime} \mathrm{E}$ ) in north Taiwan, (2) the northeastern Taiwan Strait (NETS, 24.48' N, 119 $55^{\prime} \mathrm{E}$ ), and (3)

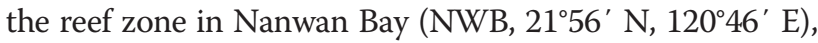
south Taiwan (Figure 1, Table 1). Samples from DRE and NETS were collected by bottom trawl onboard the Ocean Research Vessel II and from a fishery vessel, respectively. At NWB, hydroid sampling on a coral reef was undertaken at 12 to $15 \mathrm{~m}$ depth using self-contained underwater with breathing apparatus (SCUBA) and at $100 \mathrm{~m}$ depth using a remotely operated vehicle (ROV). A total of 24 worm tube specimens collected at the coral reef site by SCUBA diving, and two additional ones using the ROV, were examined for hydroid associates. Specimens were preserved in seawater with $5 \%$ to $10 \%$ buffered formalin immediately after collection.

\section{Hydroids identification}

In the laboratory, each sample for taxonomic identification was dissected on a glass slide with the help of a dissecting microscope. Identification of species was undertaken using recent taxonomic keys and relevant references, including Vervoort (1966), Millard (1975), Rees and Vervoort (1987), Calder (1988, 1991a, 1997, 2012), Hirohito (1988, 1995), Cornelius (1995a, 1995b), Schuchert (1996, 1998, 2001, 2003, 2004), Marques (2001), and Vervoort and Watson (2003).

\section{Results}

Hydroids from DRE and NETS, collected by bottom trawl, were often found together with rocks. However, those actually attached to rock at DRE represented less than $30 \%(N>100)$ of the total number of specimens. At NETS, hydroids were found tangled in the trawl net because most colonies were fragmented and longer than $40 \mathrm{~cm}$. Worm tubes, an important substrate at NWB, supported a substantial growth of sessile organisms including hydroids, soft corals, ascidians, and red algae (Figure 2). As for hydroids, they were associated with worm tubes at the rate of $100 \%(N=24)$. Most hydroids attached to middle and distal surfaces of the tube, while fewer were present at the base.

In our samples, 22 species were identified from riverbed environments at DRE, 11 epizoic species were found on worm tubes at NWB, and 1 species occurred in

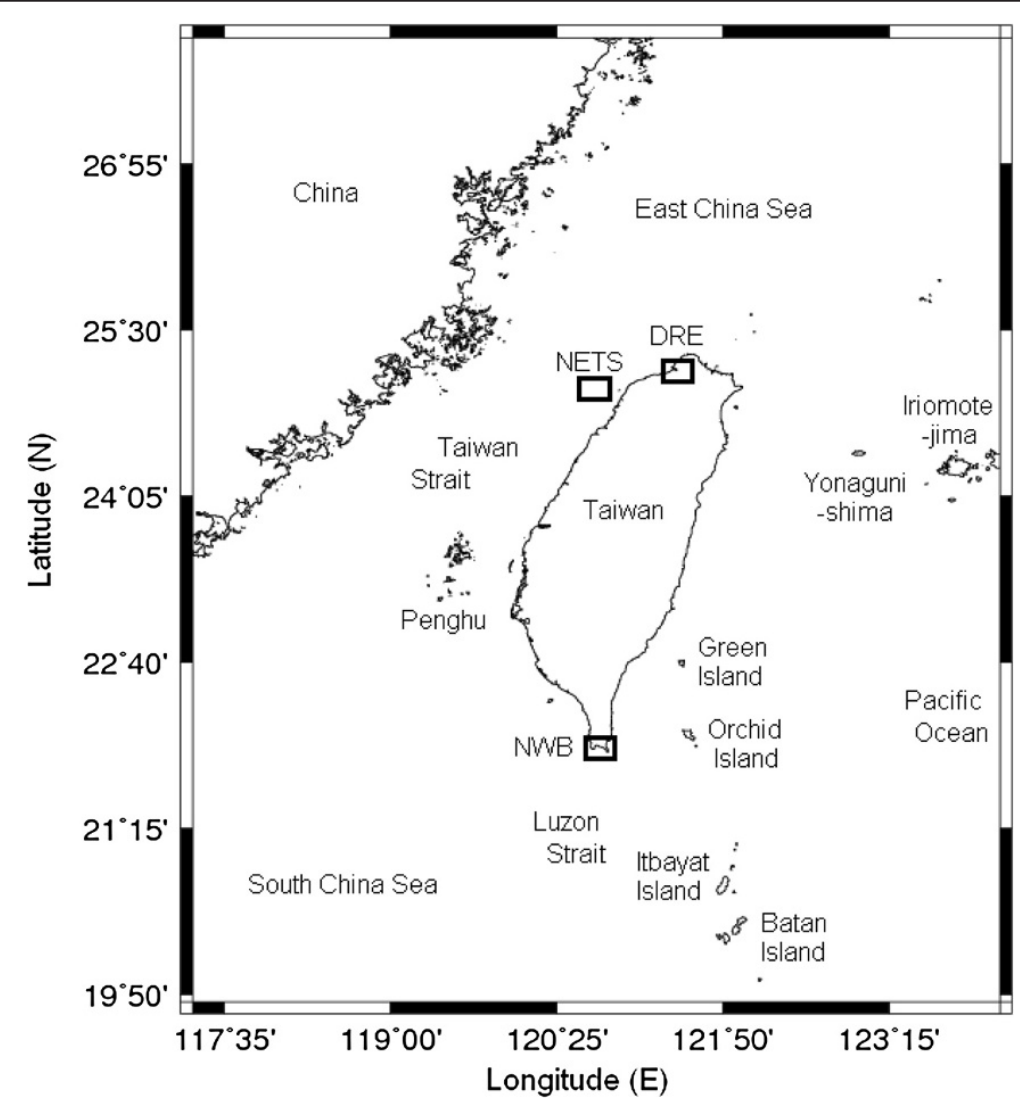

Figure 1 Map of Taiwan and vicinity, showing the three sampling locations. DRE, Danshuei River estuary; NETS, northeastern Taiwan Strait; NWB, Nan-Wan Bay. 
Table 1 Sampling location, date, depth, and methods

\begin{tabular}{lccc}
\hline Sampling area & Date & Depth $(\mathbf{m})$ & Methods \\
\hline Estuary of Danshuei River & 21 Aug. 2009 & 10 to 15 & ORII CR-1662, bottom trawling \\
Northeastern Taiwan Strait & 14 Mar. 2009 & 50 to 60 & Fishery boat, bottom trawling \\
Reef zone of Nan-Wan Bay & 22 Dec. 2009 & 5 to 10 & SCUBA diving \\
Reef zone of Nan-Wan Bay & Aug. 2008 & 100 & Remotely operated vehicle \\
\hline
\end{tabular}

ORII, Ocean Research Vessel II.

samples from NETS (Table 2). Overall, a total of 33 hydroid species (12 of them identified solely to generic level and 1 to family level) referable to 22 genera, 12 families, and 2 orders, were discovered. Most of the species belonged to order Leptothecata $(84.8 \%)$, with the remainder being referable to order Anthoathecata (15.2\%). Taking samples from all study areas together, hydroids of the family Sertulariidae (comprising 14 species, with 3 identified to generic level only) contained the largest number of species. Six species (Aglaophenia latecarinata Allman, 1877; Plumularia floridana Nutting, 1900; Diphasia palmata Nutting, 1905; Dynamena brevis (Fraser, 1935); Dynamena obliqua Lamouroux, 1816; and Synthecium elegans Allman, 1872) are recorded here for the first time from waters adjacent to mainland China (Table 2).

Hydroid species composition and abundance varied considerably between DRE and NWB. Only one species, Plumularia habereri Stechow, 1909, was found at both locations. Species found in the deep zone at NWB by the ROV were $P$. habereri and Dynamena nanshaensis Tang, 1991a. At NETS, only one species was found, the robust aglaopheniid Monoserius pennarius (Linnaeus, 1758). Its colony had a single stem, with pinnate side branches.

\section{Discussion}

Historical records of hydroids in coastal waters around Taiwan are limited. Yeh (1995) reported seven species of
Plumulariidae collected in the southern part of the island. Hwang and Shao (1998) described two venomous hydroids from the same location. Kubota et al. (1999) provided the first record of Eugymnanthea japonica (Yamada, 1950) (Leptothecata, Eirenidae), from western Taiwan, where it was associated with two bivalve species (Crassostrea gigas (Thunberg, 1793), Perna viridis (Linnaeus, 1758)). Recently, Fontana et al. (2012) reported what was believed to be a cosmopolitan and possibly genus-specific association between Zanclea spp. and its coral hosts, based in part on hydroids from Acropora corals on reefs in Kenting and the Penghu Islands, Taiwan. Previous literature provided li`mited data of hydroids in this area, as shown in the extensive review on hydroid species in Chinese waters by Liu (2008). His report recorded 615 species of Hydrozoa in waters adjacent to mainland China, including the East China Sea, western Taiwan Strait, and South China Sea. Shortly after, Huang and Lin (2012) provided illustrations of 829 species of Hydrozoa in waters adjacent to mainland China. However, hydroids in the eastern Taiwan Strait were still inadequately known, and our study is the first to document the hydroid fauna in waters of the region.

The stinging hydroid Aglaophenia cupressina Lamouroux, 1816 is widely distributed on the coral reefs of the Bunaken area (Ricciardi 2007). Tang (1991a) noted that the sting of A. cupressina, frequent on reefs in the Indo-West Pacific area, produces an itchy rash in humans. Hwang and Shao
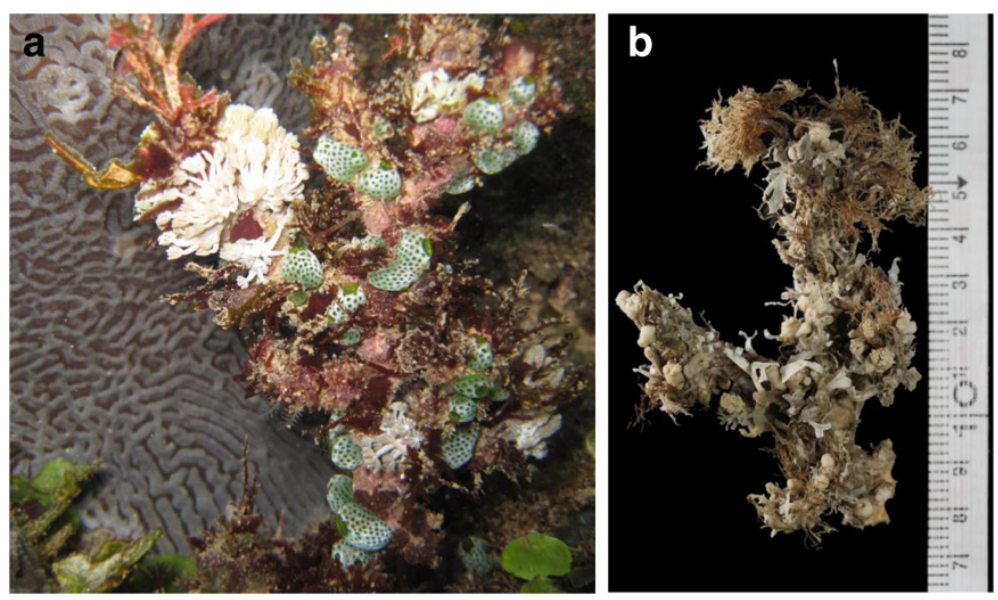

Figure 2 Photographs of worm tubes in field (a) and colony size (b) taken from the coast of Nan-Wan Bay. 
Table 2 Taxonomic list of hydroids collected from north and south Taiwan

\section{Scientific classification}

\section{Hydrozoa}

Order Anthoathecata Cornelius, 1992

Bougainvilliidae Lütken, 1850

Bimeria sp.

Eudendriidae L. Agassiz, 1862

Eudendrium sp. 1

Eudendrium sp. 2

Eudendrium sp. 3

Pennariidae McCrady, 1859

Pennaria disticha Goldfuss, 1820

Order Leptothecata Cornelius, 1992

Aglaopheniidae Marktanner-Turneretscher, 1890
Aglaophenia cupressina Lamouroux, 1816

Aglaophenia latecarinata Allman, $1877^{\mathrm{a}}$

Macrorhynchia philippina Kirchenpauer, 1872

Monoserius pennarius (Linnaeus, 1758)

Campanulariidae Johnston, 1836

Campanulariidae indet.

Obelia dichotoma (Linnaeus, 1758)

Halopterididae Millard, 1962

Halopteris sp.

NWB

DRE

DRE

NETS

DRE

DRE

NWB

Hebellidae Fraser, 1912

Hebella sp.

Kirchenpaueriidae Stechow, 1921

Kirchenpaueria sp.

Lafoeidae Hincks, 1868

Zygophylax sp.

Plumulariidae Agassiz, 1862

Nemertesia sp.

Plumularia habereri Stechow, 1909

Plumularia floridana Nutting, $1900^{a}$

Sertulariidae Lamouroux, 1812

Diphasia digitalis (Busk, 1852)

Diphasia palmata Nutting, $1905^{\text {a }}$

Dynamena brevis (Fraser, 1935)

Dynamena crisioides Lamouroux, 1824

Dynamena disticha (Bosc, 1802)

Dynamena nanshaensis Tang, 1991

Dynamena obliqua Lamouroux, $1816^{\text {a }}$

Dynamena quadridentata (Ellis and Solander, 1786)

Idiellana pristis (Lamouroux, 1816)

Salacia sp

Sertularella diaphana (Allman, 1885)

DRE

DRE

DRE

DRE

NWB

DRE

DRE

DRE

NWB

DRE

DRE

DRE

DRE

NWB

DRE
NWB

Recorded in Liu (2008)

DRE

DRE

NWB

NWB

ECS, SCS, CTR-STR, MEDIT

XSHA, NSHA, SAFRI, EAFRI, INMA, AU

SCS, CTR-STR

ECS, SCS, IWPAC

YS, ECS, SCS, COSMOP

DRE, NWB (ROV)

NWB (ROV)
SCS, ID, JP, CARIB

SCS, CTR-STR

ECS, SCS, CTR-STR

ECS, SCS, ID, JP, BM, BR (Synonym, Dynamena cornicina McCrady, 1859) NSHA

ZJ, FJN, HK, TKG, CTR-STR

ECS, SCS, CTR-STR

ECS, CTR-STR 


\section{Table 2 Taxonomic list of hydroids collected from north and south Taiwan (Continued)}

\begin{tabular}{|c|c|c|}
\hline Sertularella sp. & NWB & - \\
\hline Sertularia loculosa Busk, 1852 & DRE & SCS, WAFRI, SAFRI, LK, ID, JP (Synonym, Sertularia ligulata Thornely, 1904) \\
\hline Sertularia sp. & DRE & - \\
\hline \multicolumn{3}{|c|}{ Syntheciidae Marktanner-Turneretscher, 1890} \\
\hline Synthecium elegans Allman, $1872^{a}$ & DRE & - \\
\hline
\end{tabular}

${ }^{\mathrm{a}}$ First record of the species in waters adjacent Mainland China. DRE, Danshuei River estuary; NETS, northeastern Taiwan Strait; NWB, Nan-Wan Bay. Distributions of certain species as recorded in Liu (2008). AU, Australia; BM, Bermuda; BR, Brazil; CARIB, Caribbean; COSMOP, Cosmopolitan; CTR-STR, Circumtropical-Subtropical; EAFRI, East Africa; ECS, East China Sea; FJN, Fujian; HK, Hong Kong; ID, Indonesia; INMA, Indo-Malaysia; IWPAC, Indo-West Pacific; JP, Japan; LK, Sri Lanka; MEDIT, Mediterranean; NSHA, Nansha Islands; SAFRI, South Africa; SCS, South China Sea; TKG, Tonkin Gulf; WAFRI, West Africa; XSHA, Xisha Islands; YS, Yellow Sea; ZJ, Zhejiang.

(1998) reported $A$. cupressina and the feather hydroid Halocordyle disticha (a synonym of Pennaria disticha Goldfuss, 1820), both venomous to humans, in Taiwan. Eldredge and Smith (2001) noted that the sting of $P$. disticha causes mild irritation in humans. The two species were recorded on worm tubes from NWB in our study.

The colonial hydroid $P$. habereri was found in a riverbed environment at DRE and by ROV in NWB. This species is widely distributed in the South China Sea, Indonesia, and Japan (Liu 2008) at varied depth ranges, e.g., 10 to $35 \mathrm{~m}$ (Schuchert 2003) and 1 to $4 \mathrm{~m}$ (Calder and Kirkendale 2005). In our study, the species was collected at a depth of $100 \mathrm{~m}$, the deepest ever recorded. In addition, waters in the estuarine environment at DRE have a wide range of salinities. We conclude that $P$. habereri is a euryhaline species.

A noteworthy discovery in our samples was D. nanshaensis, collected from hard substrates on the reef at NWB. This is only the second record of the species since its original description from the Nansha Islands (Tang 1991a). Thus far, D. nanshaensis is known only from the South China Sea, specifically from the type locality (Nansha Islands, about $10^{\circ} \mathrm{N}$ ) and now from our study in Nanwan Bay (about $21^{\circ} 56^{\prime} \mathrm{N}$ ), south Taiwan, the northernmost record of the species.

The macrobenthic hydroid $M$. pennarius was especially abundant at Nansha Island (Zhao 1998; Tang 1991b). Its dense population there establishes an ecological environment described as an 'imitative steppe on sea floor' (Zhao 1998) and a 'sea-floor prairie' (Tang 1991b). M. pennarius is widely distributed in the Indo-Malayan and Sino-Japanese subregions of the Indo-West Pacific region (Tang 1991b), including India, Ceylon, Indonesia, Philippines, Taiwan, southern Japan, Palau, and New Zealand (Schuchert 2003). It is a species of warm waters and high salinity in the East China Sea (Liu and Li 2002). Common macrobenthic communities there include: Callianassa spp., M. pennarius-Stellaster equestris (Tang and Xu 1978), and S. equestris, M. pennarius-Callianassa japonica (Liu and Li 2002). Our material from NETS confirmed that colony length of $M$. pennarius ranges from 30 to $100 \mathrm{~cm}$ and that it inhabits muddy-sandy seabeds at depths of 50 to $100 \mathrm{~m}$ (Tang 1991b; Schuchert 2003; Vervoort and Watson 2003).

Samples from DRE included the cosmopolitan species Dynamena disticha (Bosc, 1802). Liu (2008) reported D. disticha from the East China Sea, South China Sea, Indonesia, Japan, Bermuda, and Brazil. Puce et al. (2009) reported that $D$. disticha can be found in association with algae, hydroids, barnacles, rocks, and concretions in the Mediterranean Sea. This suggests high adaptability to diverse environments, and indeed, $D$. disticha has a broad distribution. Some hydroids form communities in association with other co-occurring marine organisms. Fraschetti et al. (2006) reported D. disticha and Obelia dichotoma (Linnaeus, 1758) in association with brown algae Cystoseira amentacea (C.Agardh) Bory de SaintVincent, 1832 in the Mediterranean Sea. Both hydroid species were recorded from DRE in this study. Cunha and Jacobucci (2010) reported 16 species of hydroids on fronds of the alga Sargassum cymosum C.Agardh, 1820 in subtropical Brazil. Among species in their list, A. latecarinata, $D$. disticha, and $O$. dichotoma were also found in our study. Gravier-Bonnet and Bourmaud (2006) recorded 95 hydroid species from a reef zone in the southwest Indian Ocean, with $P$. disticha, A. cupressina, Macrorhynchia philippina, and Dynamena crisioides being common to abundant. Three of these species (P. disticha, A. cupressina, and D. crisioides) were also identified from samples in the reef zone at NWB.

Notably, six species (A. latecarinata, P. floridana, D. palmata, D. brevis, D. obliqua, and S. elegans) identified from DRE have never been recorded previously in seas of China (Liu 2008). This reveals that the assemblage of hydroids in the eastern Taiwan Strait differs significantly from those in coastal waters of mainland China. Shao (1998) estimated that the number of marine species around Taiwan represented $10 \%$ of the total number known worldwide. The island of Taiwan, located in the west Pacific Ocean, has a total of 1,566 kilometers of coastline (including the Penghu Islands) (Tung 2006), and complex current systems influence the island (Tseng et al. 2013a, b). Diverse water masses of the East China 
Sea, South China Sea, China Coastal Current, and Kuroshio Current have a pronounced effect on the endemic marine biota. Varied marine habitats promote a highly diversity biota around Taiwan Island (Shao 2009). Expanding the geographic scope and frequency of marine surveys would potentially show that the indigenous hydroid fauna in waters around Taiwan is even richer.

\section{Conclusions}

The study documents a unique and heterogeneous assemblage of hydroids found in three quite dissimilar marine environments in Taiwan (DRE, NETS, and NWB). The DRE riverbed system supports a comparatively richer hydroid fauna than a group of species associated with worm tubes from NWB. The three sampling sites differed significantly in faunal composition and numbers of species. Differences are attributed primarily to disparities in substrate types and salinity characteristics among the sites. Studies on developmental stages of hydroids under laboratory conditions are needed to better understand their life cycles in nature.

\section{Competing interests}

The authors declare that they have no competing interests.

\section{Authors' contributions}

Specimen collection at DRE and NETS was carried out by CHW. At NWB, samples were collected using SCUBA by LCT and CHW, while ROV samples were collected by WHT. ZCT completed the taxonomic work of hydroid species identification. LCT and CHW took photographs of worm tubes in the field and in the laboratory, respectively. LCT analyzed the data, prepared figures and tables, and drafted the manuscript. LCT and JSH finalized the manuscript. All authors read and approved the final manuscript.

\section{Acknowledgements}

This manuscript was completed thanks in large part to Professor Z.-C. Tang, who passed away on 18 August 2011 during the study. His efforts and dedication to the taxonomic component of the work are greatly appreciated. Thanks to Mrs. Tang (Mei-Jun Huang) for assisting in screening hydroid samples. Thanks are due to Professor Santosh Kumar Sarkar (Department of Marine Science, University of Calcutta, India), whose comments and advice improved the paper. We thank two anonymous referees for their editing and suggestions that substantially improved the quality of the manuscript. We are grateful for financial support from the Ministry of Science and Technology of Taiwan via projects NSC 100-2611-M019-010; NSC 101-2611-M-019-011 and NSC 102-2611-M-019-003 to J.-S. Hwang. Our appreciation is extended to members of J-S. Hwang's laboratory and to the captain and technicians of Ocean Research Vessel II for their assistance during field sampling of hydroids in Danshuei River estuary.

\section{Author details}

${ }^{1}$ Institute of Marine Biology, College of Life Sciences, National Taiwan Ocean University, 2 Pei-Ning Road, Keelung 20224, Taiwan. ${ }^{2}$ Institute of Life Science, National Taitung University, 684, Sec. 1, Chunghua Road, Taitung 95092, Taiwan. ${ }^{3}$ Institute of Oceanology, Academia Sinica, Qingdao 266071, China.

Received: 17 February 2014 Accepted: 19 May 2014

Published online: 10 June 2014

\section{References}

Calder DR (1988) Shallow-water hydroids of Bermuda: the Athecatae. R Ont Mus Life Sci Contrib 148:1-107

Calder DR (1991a) Shallow-water hydroids of Bermuda: the Thecatae, exclusive of Plumularioidea. R Ont Mus Life Sci Contrib 154:1-140
Calder DR (1991b) Association between hydroid species assemblages and substrate types in the mangal at Twin Cays, Belize. Can J Zool 69:2067-2074

Calder DR (1997) Shallow-water hydroids of Bermuda: superfamily Plumularioidea. R Ont Mus Life Sci Contrib 161:1-107

Calder DR (2012) On a collection of hydroids (Cnidaria, Hydrozoa, Hydroidolina) from the west coast of Sweden, with a checklist of species from the region. Zootaxa 3171:1-77

Calder DR, Kirkendale L (2005) Hydroids (Cnidaria, Hydrozoa) from shallow-water environments along the Caribbean coast of Panama. Caribb J Sci 41:476-491

Hargitt CW (1924) Hydroids of the Philippine Islands. Philipp J Sci 24:467-505

Cornelius PFS (1995a) North-west European thecate hydroids and their medusae. Part 1: Introduction, Laodiceidae to Haleciidae. Synopses Br Fauna (ns) 50:347

Cornelius PFS (1995b) North-west European thecate hydroids and their medusae. Part 2: Sertulariidae to Campanulariidae. Synopses Br Fauna (ns) 50:386

Cunha AF, Jacobucci GB (2010) Seasonal variation of epiphytic hydroids (Cnidaria: Hydrozoa) associated to a subtropical Sargassum cymosum (Phaeophyta: Fucales) bed. Zoologia 27:945-955

Eldredge LG, Smith CM (2001) A guidebook of marine introduced species in Hawaii. Bishop Mus Tech Rep 21:1-80

Fraschetti S, Terlizzi A, Bevilacqua S, Boero F (2006) The distribution of hydroids (Cnidaria, Hydrozoa) from micro- to macro-scale: spatial patterns on habitatforming algae. J Exp Mar Biol Ecol 339:148-158

Fontana S, Keshavmurthy S, Hsieh HJ, Denis V, Kuo CY, Hsu CM, Leung JK, Tsai WS, Wallace CC, Chen CA (2012) Molecular evidence shows low species diversity of coral-associated hydroids in Acropora corals. PLoS ONE 7:e50130

Genzano GN (2002) Associations between pycnogonids and hydroids from the Buenos Aires littoral zone, with observations on the semi-parasitic life cycle of Tanystylum orbiculare (Ammotheiidae). Sci Mar 66:83-92

Gili J, Hughes RG (1995) The ecology of marine benthic hydroids. Oceanogr Mar Biol Annu Rev 33:351-426

Gravier-Bonnet N, Bourmaud C (2006) Hydroids (Cnidaria, Hydrozoa) of coral reefs: preliminary results on community structure, species distribution and reproductive biology in Juan de Nova Island (Southwest Indian Ocean). West Indian Ocean J Mar Sci 5:123-132

Henry L-A (2001) Hydroids associated with deep-sea corals in the boreal north-west Atlantic. J Mar Biol Ass U K 81:163-164

Hirohito, Emperor of Japan (1988) The hydroids of Sagami Bay. (Part 1. Athecata). Publs. Biol. Lab., ImpHousehold, Tokyo

Hirohito, Emperor of Japan (1995) The hydroids of Sagami Bay II. Thecata. Publs. Biol. Lab., Imp. Household, Tokyo

Huang Z, Lin M (2012) An illustrated guide to species in China's Seas (volume 3) Animalia (1): Porifera, Cnidaria Plathyelminthes, Nemertinea, Nematoda, Acanthocephala, Rotifera, Gastrotricha, Kinorhyncha, Priapulida, Annelida, Sipuncula, Echiura. The living species and their illustrations in China's Seas (Part II). China Ocean Press, Beijing, China, in Chinese

Hwang DF, Shao KT (1998) Illustrations of toxic fishes and shellfishes in Taiwan, 2nd edn. Cheng Chung Book Co., Ltd. Taipei (in Chinese)

Jäderholm E (1903) Aussereuropäischen Hydroiden im schwedischen Reichsmuseum. Arkiv Zoologi 1:259-312

Kubota S, Dai C-F, Lin C-L, Ho J-S (1999) The first occurrence of the paedomorphic derivative hydrozoan Eugymnanthea (Leptomedusae, Eirenidae) from Taiwan, with a report of a new host. Publ Seto Mar Biol Lab 38:219-222

Liu R (2008) Checklist of marine biota of China Seas. Science Press, Academia Sinica, Beijing (in Chinese)

Liu L-S, Li X-Z (2002) Distribution of macrobenthos in spring and autumn in the East China Sea. Biodiv Sci 10:351-358

Marques AC (2001) Simplifying hydrozoan classification: inappropriateness of the group Hydroidomedusae in a phylogenetic context. Contr Zool 70:175-179

Millard NAH (1975) Monograph on the Hydroida of southern Africa. Ann S Afr Mus 68:1-513

Oliveira OMP, Marques AC (2007) Epiphytic hydroids (Hydrozoa: Anthoathecata and Leptothecata) of the world. Check List 3:21-38

Puce S, Bavestrello G, Di Camillo CG, Boero F (2009) Long-term changes in hydroid (Cnidaria, Hydrozoa) assemblages: effect of Mediterranean warming? Mar Ecol 30:1-14

Rees WJ, Vervoort W (1987) Hydroids from the John Murray Expedition to the Indian Ocean, with revisory notes on Hydrodendron, Abietinella, Cryptolaria and Zygophylax (Cnidaria: Hydrozoa). Zool Verh Leiden 237:1-209

Ricciardi F (2007) First record of a color variation of Cuthona diversicolor (Tergipedidae: Aeolidina) feeding on the hydroid, Aglaophenia cupressina, on a North Sulawesi (Indonesia) coral reef. Zool Stud 46:473 
Schuchert P (1996) The marine fauna of New Zealand: athecate hydroids and their medusae. NZ Oceanogr Inst Mem 106:1-159

Schuchert P (1998) How many hydrozoan species are there? Zool Verh Leiden 323:209-219

Schuchert P (2001) Hydroids of Greenland and Iceland (Cnidaria, Hydrozoa). Medd Grønland, Biosci 53:1-184

Schuchert P (2003) Hydroids (Cnidaria, Hydrozoa) of the Danish expedition to the Kei Islands. Steenstrupia 27:137-256

Schuchert P (2004) Revision of the European athecate hydroids and their medusae (Hydrozoa, Cnidaria): families Oceanidae and Pachycordylidae. Rev Suisse Zool 111:315-369

Schuchert P (2009) The European athecate hydroids and their medusae (Hydrozoa, Cnidaria): Filifera Part 5. Rev Suisse Zool 116:441-507

Shao KT (1998) Marine ecology. National Press Company, Ming Wen Book Co. Ltd, Taipei, Taiwan, in Chinese

Shao KT (2009) Marine biodiversity and fishery sustainability. Asia Pac J Clin Nutr 18:527-531

Tang ZC (1991a) On a collection of hydroida from the Nansha Islands, Hainan Province, China. Researches on the marine biology of Nansha Islands and neighboring waters collected papers (I):25-36. Ocean Publishing Press, Beijing, In Chinese, with English abstract

Tang ZC (1991b) Monoserius pennarius assemblage and its ecological and geographical studies on the continental shelf of waters around the Nansha islands, South China Sea. Researches on the marine biology of Nansha Islands and neighboring waters collected papers (II). 255-261. Ocean Publishing Press, Beijing, In Chinese with English abstract

Tang ZC (1998) A new species of the genus Filellum (Hydrozoa: Lafoeidae) from the waters around Nansha Islands, South China Sea. Studies on marine fauna and flora and biogeography of the Nansha Islands and neighbouring waters III:42-46. Ocean Publishing Press, Beijing, In Chinese, with English abstract

Tang ZC, Huang MJ (1986) A new species of the genus Symplectoscyphus (Hydroida) from the Huanghai Sea. Chin J Oceanol Limnol 4:317-318

Tang ZC, Xu FS (1978) Preliminary analysis of the distribution and community of macrobenthos from the continental shelf of the East China Sea. In: Transactions of the Continental Shelf of the East China Sea, Institute of Oceanology, Chinese Academy of Sciences, Qingdao, pp 156-164, In Chinese

Tseng L-C, Dahms H-U, Chen Q-C, Hwang J-S (2013a) Geospatial variability of autumn community structure on epipelagic zooplankton in the upper layer of the northern South China Sea. Zool Stud 52:2

Tseng L-C, Hung J-J, Chen Q-C, Hwang J-S (2013b) Seasonality of the copepod assemblages associated with interplay waters off northeastern Taiwan. Helgoland Mar Res 67:507-520

Tung C-Y (2006) Prospects of the Taiwan Strait west coast economic zone. In: Davidson P (ed) Trading arrangements in the Pacific Rim: ASEAN and APEC (New York: Oceana Publications, May 2006), Document III. C, vol 10., pp 1-8 Vervoort W (1966) Bathyal and abyssal hydroids. Galathea Rep 8:97-174

Vervoort W (1995) Bibliography of Leptolida (non-siphonophoran Hydrozoa, Cnidaria). Works published after 1910. Zool Verh Leiden 301:1-432

Vervoort W, Watson JE (2003) The marine fauna of New Zealand: Leptothecata (Cnidaria: Hydrozoa) (Thecate hydroids). Natl Inst Water Atmos Res (NIWA) Biodivers Mem 119:1-538

Xu Z, Huang J (2004) On new species and record of Laingiomedusae and Leptomedusae (Cnidaria, Hydrozoa, Hydroidomedusae) in the Taiwan Strait. J Xiamen Univ (Nat Sci) 43:107-114

Yeh Y-C (1995) Morphology of Plumulariidae hydroida in Taiwan, M Sc. thesis. Institute of Marine Biology. National Sun Yat-Sen University, Kaohsiung, Taiwan, In Chinese, with English abstract

Zhao H (1998) Type and evolution of landscapes of Nansha Islands. Chin Geogr Sci 8:144-151

doi:10.1186/s40555-014-0029-z

Cite this article as: Tseng et al.: Hydroids (Cnidaria, Hydrozoa) from marine environments in Taiwan. Zoological Studies 2014 53:29. 